\title{
Artelogie
}

Recherche sur les arts, le patrimoine et la littérature de l'Amérique latine

$2 \mid 2012$

Mexique : espace urbain et résistances artistiques et littéraires face à la « ville générique »

\section{Urban imaginaries of Mexican victimism: the images of silence}

Johanna Lozoya

\section{OpenEdition}

\section{Journals}

Electronic version

URL: https://journals.openedition.org/artelogie/7603

DOI: $10.4000 /$ artelogie.7603

ISSN: 2115-6395

Publisher

Association ESCAL

\section{Electronic reference}

Johanna Lozoya, "Urban imaginaries of Mexican victimism: the images of silence", Artelogie [Online],

2 | 2012, Online since 21 January 2012, connection on 07 January 2022. URL: http://

journals.openedition.org/artelogie/7603 ; DOI: https://doi.org/10.4000/artelogie.7603

This text was automatically generated on 7 January 2022.

Association ESCAL 


\title{
Urban imaginaries of Mexican victimism: the images of silence
}

\author{
Johanna Lozoya
}

- Looking at the stars? - No I'm looking at the

Dark Matter. Ninety nine percent of the universe

... Dark Matter.

Film Dark Matter, Shi-Zheng Chen

\section{Introduction}

Universe can be thought as an enormous mountain range in which stars are the visible highlands. All the rest, the slopes, the hillsides covered by the mist, is dark matter. We can't see it, but it is just right there, beneath the shiny peaks. Mexico City, a megalopolis of more than twenty million people, is quite a universe. Not exactly the modern urban setting that since the thirties historians like to imagine as a Musilian city, that industrial world where people are pressed and pour among roofs, buses and fading industrial lights, as Georg Heym would express. Nor is it a tropical impressionist scenary where an epic past and a (in)dependant future seems to apply to Paul Ricoeur's postcolonial paradox: how to become modern and turn back to origins; how to deal with the revival of an old civilization and still be a modern one. Yet, we can be certain that Mexico City is a modern city (RICOEUR, 1965: p. 271-284). It has the proper clear hights of modernity (including generic imaginaries) just as it veils a silent complex dark matter: the modern invention of a victimist identity.

2 Why silent? A couple of years ago reading Daniel Barenboim's Music Quickens Time, the following paragraph struck me. "Sound is not independent", he writes," - it does not exist by itself, but has a permanent, constant and unavoidable relationship to silence. In this context the first note is not the beginning, but comes out of the silence that precedes it" (BARENBOIM, 2009: p. 7). The idea of sound being pull out of silence through an almost anti-gravitational action that struggles for sound not to collapse again into the silent magma, is not a new image. What interested me in Barenboim's 
idea, was the image of silence being a sound. Not nothingness, nor emptiness, but the original substratum from which other type of sounds area lifted, and with a certain amount of energy sustained from being driven again into it. A dependant association between sound and silence is at stake; neither of them can be independent, but each one can be shockingly expressive.

3 As a matter of fact, sound - specially in the noisy Western world we live in where everything has to be said, shown, expressed, unveiled - resembles the shiny stars or the visible heights of our modern universe. Underneath - like the hillsides which are not heard, seen, or expressed in the heights but vitally associated to them - silence is just right there. Behind the mist of modern reason and sound clarity, silence's impressionist nature, in real and metaphorical sense (as in Édouard Manet's Gare Saint Lazare (The Railway) where the title of the painting announces what it is not shown: the smoke of an engine hides the train) silence can be envisaged as the substratum of the unshadowed and clear cristal rationalist modern world.

4 In such a way, the construction of cultural victimism rests silently behind the mist of Mexico City's urban contemporary traditional and generic city's imaginaries.

\section{Dark Matter}

I

5 In the past few decades, Mexico City's cultural imaginaries have been changed by fictions in which tradition and modernity, past and future, are blended or crashed? Yes. Have the cultural, social, economical dynamics of the generic city - in terms of Rem Koolhas - triggered such fictions weakening the traditional imaginaries in this city such as cultural and political identities. Not really, not yet, no need. Why?

6 Tradition, in contemporary Mexican cultural imaginaries, has a complex and powerful link with modern nationalism. Contemporary tradition - imagined as mexicanidad - is a cultural identity born (significantly) from the political nationalist imaginaries of the Mexican state of the second half of the twentieth century. This means, that modern mexicanidad is an ultra nationalist political construction still effective in Mexico's political and daily life (LOZOYA, 2005, Lyon). One of the most interesting and tricky features of this modern traditional identity is its fierce dispute with modernity (mainly thought as otherness) and it is not an uncommon idea among Mexican scholars to imagine nationalism and modernity as opposites! "What's national [lo nacional] and what's modern [lo moderno] were issues mutually exclusive", says Ramon Vargas to explain the crisis in the twenties of the Neocolonial Style [Spanish Style]; "the dreamed Mexican man, should represent the paradox of being simultaneously modern and Mexican, international and national", states Celia Arredondo to distinguish the Functionalist architecture developed in the fifties (VARGAS, 1994: P. 94; ARREDONDO, 1998: p. 91). In the other hand, the bizarre Mexican opposition (nationalism vs modernity) is argued not through knowledge but through an unquestionable faith (and not critical understanding) of nationalist identities in the face of otherness, I believe myself Mexican. "You are Mexico. Celebrate two hundred years of proudly being Mexican", is written in the massive government propaganda for Independence Day 2010 (Bicentennial Celebrations). 


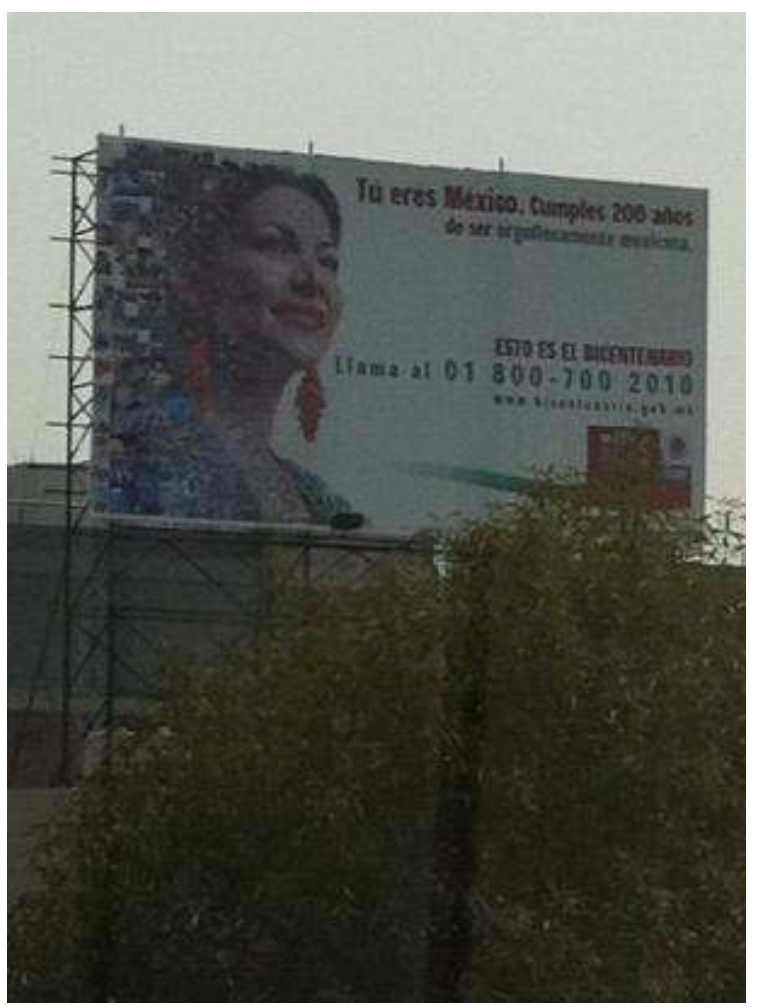

Photo: Johanna Lozoya

7 Actually, the almost religious belief in the mexicanidad as a true and ancestral identity is hardly questioned by Mexican intellectuals. From this, it can be understood why cultural irruptions of generic city's imaginaries in the Mexican cultural context are quickly sent to the grounds of this old but yet effective identitarian controversy built over a magma of multiple and historical figures of otherness.

8 Now, is it adequate to approach the cultural impact of the generic city in the belief that a true and original mexicanidad has been disrupted, and consequently a dynamic of opposites and resilience to modernity and future has been triggered? Not in my opinion. The impact of the imaginaries of the generic city (if such a city actually exists, stick to the idea of global culture) first, hasn't disrupted any ancestral tradition, and second, its impact has to be acknowledge in a magma of modern impacts constantly struggling with Mexican national faith.

9 If we consider that identity is not an essence but an historical construction that works as a tool or weapon in constant change used by individuals and communities to survive in social, political and economical conditions, tradition is no more a genuine, ancient and immutable essence that blends or crashes in modernity and future. Or at least, is no less immutable and modern than the new, intrusive and polluting identities produced by Koolhas generic city. In short, the impact of such an urban world in terms of the loss or destruction of the so called real, traditional or nationalist identities or culture in Mexico City (or, for the matter, in any other city), is a two way track essentialist argument: there is modernity and there is tradition. Both of them are the snowy, shiny peaks of a far more complex unsaid, unseen, unveiled historiographical identitary construction: a historiographical dark matter. 
Santa Fé Quarter (nowadays Mexico City's Wall Street) and El Zócalo (historical and comercial central area of the city) with "danzantes" (simulation of prehispanic dances as contemporary ritual and political expressions)
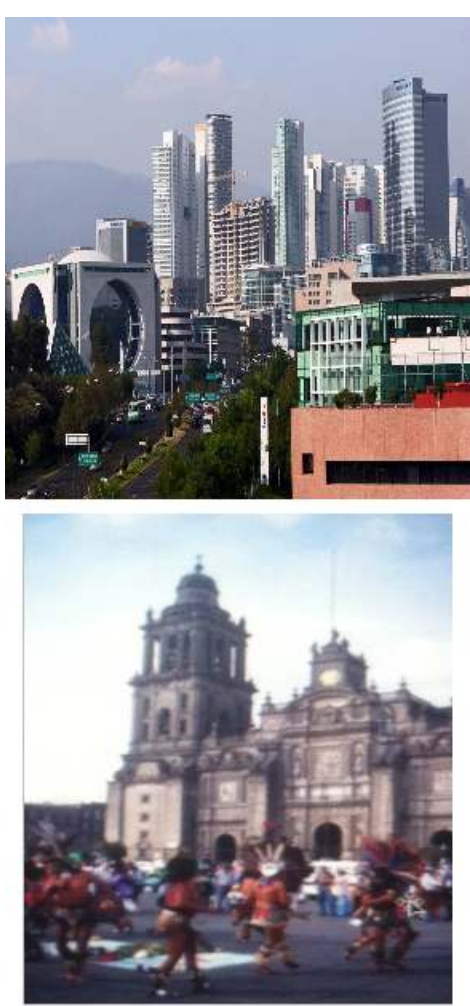

Photo: Johanna Lozoya \& internet

\section{II}

It seems that there is a couple of unavoidable statements used by contemporary Western scholars to approach any kind of problem about the Third World countries or/ and postcolonial nations: first, the idea that modernity - a sort of a cultural pack full of otherness - coexists in such worlds under unequal conditions. They have poor or weak modern cultural patterns, but instead they have a strong tradition. That is, there's an intellectual certitude that these nations have to risk a venerable, spiritual and original culture in order to be part of the modern civilization. Ricoeur, for example, says it beautifully: to be part of the modern civilization, its scientific, technical and political rationality, means more than often the abandonment of a cultural past. Traditions, then, imagined as old and true are to be protected in some sort of way from the siege of crude modernity. But some old traditions "that appear or claim to be ancient", as appointed more than twenty years ago in The Invention of Tradition (HOBSBAWM, 2002: p. 7), "are frequently recent in its origin, and sometimes are invented".

11 The second statement has to do with what Pascal Bruckner in La tyrannie de la pénitence explained as the European penitent attribution of all world misfortunes, specially of those in postcolonial countries. The European pathological sense of debt, the authors calls it. "The idea that Europe is the sick man of the planet that infects all with its pestilence, is something that the inhabitants of this continent [Europe] should be convinced of. To the question of who is guilty, metaphysically speaking, most of the people will answer 
spontaneously we are (us)". (BRUCKNER, 2008: p. 16). Ricoeur, pretty much in such spirit, explains as a natural disposition that in order to construct an independent nation, some postcolonial worlds have to display a spiritual and cultural revendication against the colonialist personality. Which means, in his terms, the revival of its true and original cultures.

12 These sorts of cultural(ist) arguments suggest more than often, that a price for living in a modern civilization has to be paid. The image of a contemporary Querelle des Anciens et des Modernes is far more complex nowadays where several enlightened dogmas, actions and utopias (or their impact still ongoing) are considered politically incorrect. Most of all, when the image of an essential difference prevails in the contemporary eye: modernity imposes with an orphan novelty and tradition looses its true essence. The global generic city in terms of Koolhaas proposal, for example, imposes over traditional urban worlds (where identity, geography, lieux and representation are important) which are doomed, eventually, to transform into non cities. Both imaginaries (anciens et modernes), nevertheless, could be seen in a different way without dooming them to the realm of a subtle failure (the non issue). One in which, tradition and modernity are not opposites but related coordinates in a same universe, such as the coextistence of stars and dark matter. That is, two dependant expressions of the same thing: the modern awareness of reality. That is, the constant invention of tradition in accordance to modernity's insatiable, mutable and neurotic need of renewing its fabricating of past.

When I wrote Ciudades sitiadas a couple of years ago, I asked contemporary Latin America's image of itself. I found out that a besieged, victimist thought was the order of the day! A world that was imagined besieged by conquests, colonialism, foreign communities, imperial powers, poverty, ignorance, violence, innocence, youth, conservatism, racial identities, cultural dependency and, above all, an astonishing inability to acknowledge itself as modern. "Modernity and development in the Latin American cultural perspective are imagined as an extravagance", I wrote in my first notes (LOZOYA, 2010: p. 11). Why is that so, I asked then, and my perplexity was intensified the following months of research when I realized that underneath all these twentieth century arguments, the main identitarian cultural regional figure was a victimist one: to the European tyrannie de la pénitence, a Latin American siège de la victime answered passionately. For each "the whole world hates us and we deserve it", a Latin American "we've become good at loosing" was found.

Underneath the nationalist identity constructions of this region expressed as venerable, original and true (among them tradition, of course), lays not a psychological issue (as Latin American intellectuals do love to argue) but a whole background of historiographical imaginaries of victimism. Actually, this complex intellectual baggage (also found beneath the Mexican contemporary imaginaries of a ancestral tradition) is surprisingly irresponsible of its own development and future. When the American journalist Michael Reid asked himself in Forgotten Continent: The Battle for Latin America's Soul, about what circumstances frustrated the sustainable development and truly democratic political structures in this region, he analyzed the literature of four schools of thought: dependence theory, cultural explanations, policy mistakes and institutional weakness. He concluded that "the burden of history is great in Latin America, but it is not absolute. The diversity of experiences across the region is a caution against a notion of inevitability." (REID, 2009: p. 51). Such a notion, he explains, comes from a contest between modernizers and reactionaries, between democrats and 
authoritarians, between the privileged and the excluded. What Reid fails to see, is that the historical imaginaries of such a contest in its contemporary expression are linked (beyond nineteenth century's historical events and the historiographical background) to the twentieth century nationalist Latin American narratives. Inevitability in the face of multiple sieges is (still) the main historiographical imaginary that holds the narrative of national irresponsibility towards (un)development, failure and crisis.

Rethinking Mexican contemporary history means a complex deconstruction (no Derrida implied!) of a historiographical corpus in which the concepts of progress, free market and democracy coexist with cultural arguments that defend the soul of nations (the irreducible Volkgeist!) and the ideological arguments of dependency theory (which beyond Mexican boundaries, has reborn (alas!) in regional populism). Modernity, then, seems not to imply the abandonment of the past culture, but the abandonment of itself (Mexico) irresponsibly, on the grounds of historiographical imaginaries of a past. These are dark matter under the shiny modern peaks of Mexican democracy, economical global policies, liberal arguments and social (supposed to be) welfare. Tradition as historiographical victimism is right there, but silenced.

Poster "La Malinche" (a historical Indian woman, mistress of Hernan Cortés) sold in a newspaper stand, Mexico City, 2011

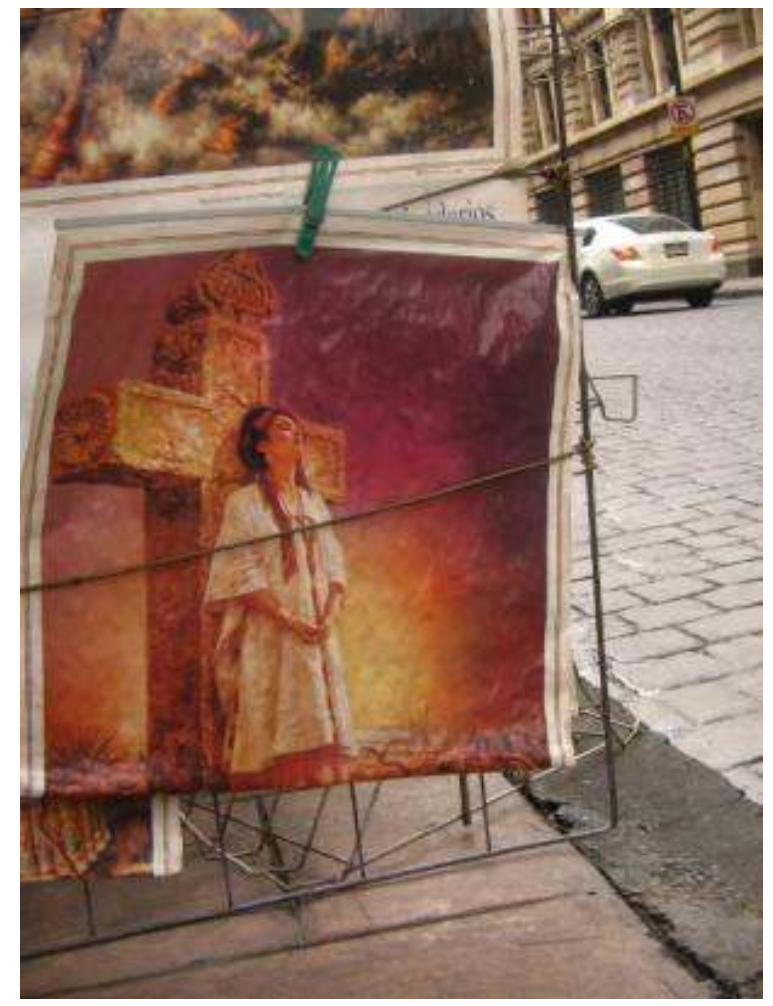

Photo: Johanna Lozoya 


\section{Silence}

\section{I}

16 How modern gadgets of Tradition and otherness can explain why the polite Mexican reply to an inquisitive or demanding expression is not dime or como dijo (tell me, sorry, what do you mean) but mande? That is, give me an order. "You don't say what,... you must say order me!", is praised as good parental education in a Father's Day congratulation postcard. Now, why a community accepts as a national well-bred tradition, such a servile, unequal and meek answer. Let's put aside Freud and culturalist arguments about Mexican passions such as those very well developed by Octavio Paz, Samuel Ramos or Carlos Fuentes, and let's have a look to other narratives in order to have a possible answer for this disturbing mande.

“¡No se dice qué se dice mande!”, Father's Day postcard, De Haro, 2011

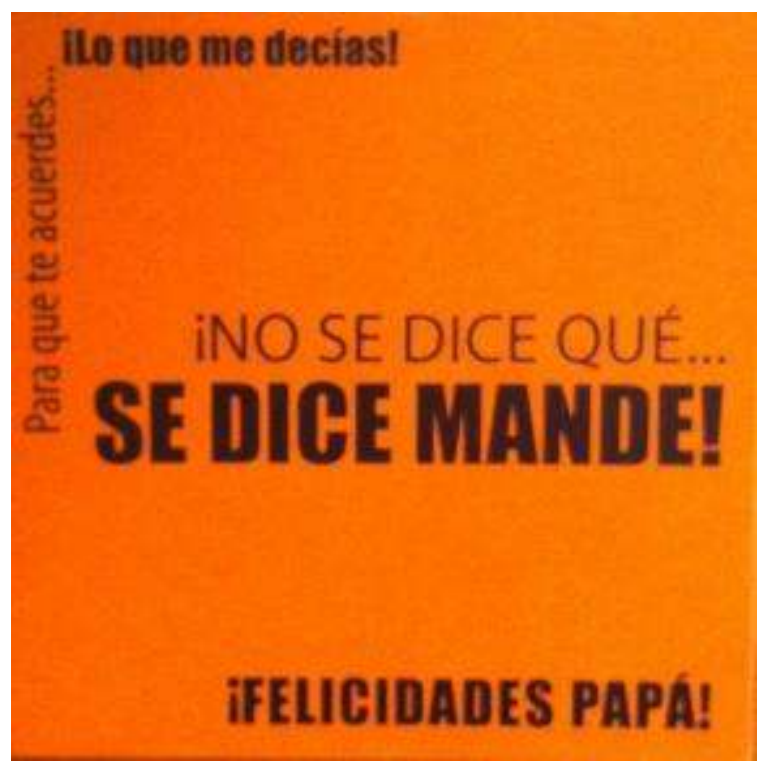

Photo Johanna Lozoya

17 If we pursue to understand the experience of modernity through its ever numbered features or elements (those of the enchanted world of the Western rationalism), we will be doing no better than defining a bird by its feathers, beak or flying ability. The taxonomical perspective has ontological limits and scientists of the eighteenth century were already aware of them. Nevertheless, when Mexico City's urban cultural imaginaries struggle vis à vis with contemporary phenomena of symbolic displacement (those perceived in global culture, generic city or gentrification, for example), it is at first understood in terms of (opposition between) elements: the public space, for example, can turn into non-lieux that in terms of Marc Augé's theory, are alienated spaces of transit or transition with excess of information, individualism and images, lacking the political and social recognition of des lieux de mémoire. The non approach (non city, non modern, non lieu) is usually determined by lists of missing canonical constituents: it is not a place, it is not rationalism, it is not public, it is not secular, it is not original and so forth. (LOZOYA, 2005, Madrid: p. 32). Theory of urbanism and architecture are full of them; no wonder why critical thought in these disciplines is so 
fond with the linguistic approach to space. Furthermore, the perception of non-modernity can be argued as the "lack of "modernity. Antonio Toca, for example, on the existence (or not) of original architecture and urbanism of emerging economies points out that "the tendency to copy the products of cultures with a major progress offers, to whom it does it and to whom it finances, the possibility of feeling at the same level of the culture that its being copied; that, is highly stimulating for both. This "mimetic" effect", the author points out, "is still evident in Mexican cultural production." (TOCA, 2004: p. 19). Paradoxically, this simplistic contemporary imaginary of cultural mimesis is supported on the quite popular theory of (cultural) dependence of the seventies (LOZOYA, 2011). Modernity is not only considered a pack of elements to be copied, but it is also the image of otherness. An alien corpus of ideas that produces an entire spectrum of emotions: fear, resentment, distrust, but just as well, admiration and envy.

In contemporary Mexican historiography the words lost and search are constantly linked with modern. It is strongly argued, for example, that during the last century the true Mexican identity was lost twice: in the Porfiriato (thirty four years of copying the French culture) and in the twenties (when the Latin American hispanismo messed up the young revolutionary minds). The search for true identity, original traditions and the venerable soul of the nation, became a priority in the so-called mexicanidad on the following decades. The revival (as in Ricoeur 's argument) of such treasures unveiled in folklore, ruins, native Indian languages or ethnographical studies of the mythical indian and the neglected modern one (who paradoxically, has never being considered as an intimate, local otherness) finally led to the true modern Mexican identity: the indigenist métissage. (LOZOYA, 2010, CONACULTA). The thing is that this particular us has been standing more than half a century, against a gigantic imaginary of otherness. Underneath the visible dependant relationship between tradition (ourness) and modernity (otherness), there is a rational, veiled construction of victimism. The subversive impact of the generic city in Mexican tradition has to line up in a long display of imagined historical besiegers!

II

19 In the nineties, Bruno Latour stated in Nous n'avons jamais été modernes. Essai d 'anthropologie symétrique, that modernity is a practice. Practice, that's a very interesting concept to consider! It reminds, in a way, of the uselessness of a general view of modernity in terms of theory of evolution (as a stage or culmination, after which postmodern conditions appear). In his work (expressed as actor-network theory in his later book Reassembling the Social) Latour argued that social forces interact with scientific knowledge. The word modern in his work defines two completely different sets of practices: one that creates social hybrids through translation (actants: networks), and another, the familiar modernity divided into two ontological areas (humans and non humans separated: critical knowledge). If the question of what is society or the social, is submitted to the first set of practices (actor-network theory) Latour's theory explains that no objects or features can be denominated as social, but the concept can be thought as a temporal practice of heterogeneous associations (between humans and non humans). Social is, in gross synthesis, a particular network of associations. This controversial social theory (even to Latour himself) offers to my own reflection about modernity, a new tool (the concept practice) to rethink the impact of it 
beyond the traditional logic of opposites: instead of determining modernity as something that is there (a sort of a fixed stage into which economical, political, social or cultural phenomena occurs and can be observed or explained), what's modern is a temporal practice of associations.

If this is so, couldn't we consider the impact of the gender city on Mexico City's traditional imaginary not as the intrusion of otherness, but as the practice of a network? One in which the relationship between what is expressed in the open ( $a$ modernity vs $a$ tradition) and its silent substratum (historiographical victimism) is a particular social network that we can define as modern(ity)? Yes, I think so. Let's put it this way: urban imaginaries of Mexican victimism, for example, are found in nets of associations between the construction of public spaces, institutional images, mass media, economical arguments, labels of products, graffiti, music, postcards, gigantic ads on freeways (ergo, in a vast network of humans and non humans). Imaginaries itself, are actants in such a network named victimism. Some of them work in the visible (picks) part of the network (for example, in government propaganda, historiography, tourist guides, local parades or civic rituals, graffiti against globalization, threatening slogans in the doors of international companies, etc.); other imaginaries work in the unvisible (slopes) part of the same network (for example, in the racist argument of Mexican métissage, in the esoteric arguments considered as traditional knowledge, in religious rituals, in ideological media, in the discourse émouvant of nationalist historiography, etc.). In the victimist network, between the picks that everybody know (modernity vs tradition) and the slopes that not everybody see (the historiographical construction of victimism) a silent practice is constructed: the modernity of tradition (mexicanidad).

21 Finally, let's have a brief and simple peep of this network in order to reconsider the impact of the gender city in the alleged weakening of Mexican tradition.

III 


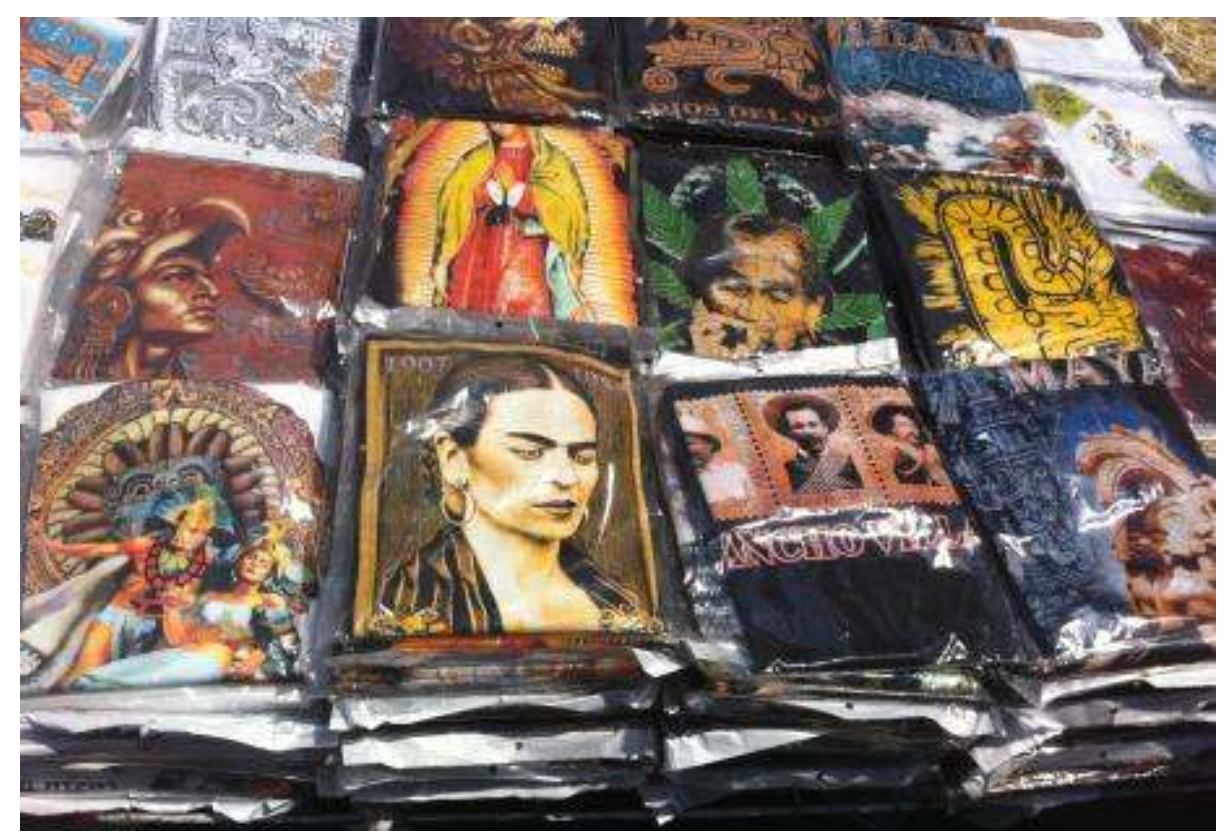

Photo: Johanna Lozoya

In the most renown public space of Mexico City, El Zócalo, these T-Shirts' images are usually in sale: Cuauhtémoc (Aztec heroe), Quetzalcóatl (Aztec god), Popocatépetl and Iztaccíhuatl (anthropomorphic image of legendary volcanoes), La Guadalupe (national Virgin), Pancho Villa (revolutionary hero), the overrated Frida Kahlo (the image of modern and revolutionary art) and the postmodern emblem of ancestral wisdom, María Sabina smoking marihuana. With these few historical images the mexicanidad is narrated by contemporary Mexicans and understood by foreigners.

These objects and images are displayed in the prime cultural and political national(ist) space of the country. Around the Zócalo (whose real name is Plaza de Armas o de La Constitución), three political powers of the Mexican nation are together: the national government's offices (Palacio Nacional), the city hall (Ayuntamiento) and the Cathedral. In this monumental plaza, Mexicans celebrate national festivities, political meetings of federal interest and the staging of rituals of mexicanidad (as shown in the previous image with danzantes).

24 This public space where the common or general knowledge is expressed (nowadays a synonymous for political space) is, for obvious reasons, opposed to what's occult or hidden. As Nora Rabotnikof points out "in the way a public space is thought, there's a previous decision about how to think politics", for in this common lieux, matters of common interest are dramatized and spoken. (RABOTNIKOF, 2005: p. 15). Which words are spoken, then, by those T-Shirts images spread all around the place by eager sellers?

At first glance (the kind that even a well-informed tourist could have), the images are the icons of a particular national history: the vinyl portraits of the Aztec heroes is a thoughtful selection about the last Pre-Hispanic highlights, only matched by the other set of national champions: the revolutionary ones. Frida and Villa represent the expressive, powerful, new, cathartic art for a straightforward, no less cathartic, revolutionary power. In between, five centuries of history are ignored (or almost ignored: it seems that New Spain's only heritage is La Virgen Morena, Guadalupe). This 
selection of images, far from being a poor one, comes from a perfectly accurate acquaintance with the national(ist) history that has being written since the fifties. This means that what's mainly narrated (in the slopes of the mountain) is the history of a great defeat.

Let's put it this way: National history in the nineteenth century's Mexican narratives, are epic stories of a cycle of birth, death and resurrection of the nation. In them, Mexico is born in mythical times previous to the conquest, destroyed in the colonial centuries and reborn three centuries later with the Independence. The Spanish Conquest which occurred in the sixteenth century meant in this historiography, the end of a civilization and the beginning of a completely different world. In such a way, the nationalist rhetoric of politicians and Mexican historians of the times, imagined, in a very complex way, the Pre-Hispanic world as antiquity, even though a paradox (in the slopes of such an image) existed: this particular antiquity, unlike Greco-Roman antiquity, was (an is) a quite unknown, alien and undecoded civilization. Extinct in such a way, that it rather resembles in the cultural progressive history of the Mexican nation, the place of the Hittites or the Sumerians in the European saga. Mexico's mother civilization, lacks of a Winckelmannian verisimilitude in the (non existent) civilizatory cycle in which the Mexican cultural saga inscribed itself. Now, the nineteenth century nationalism was not indigenista; not at least, in the contemporary meaning of the word. A hundred years ago, Mexican tradition was imagined as the western border of the Western world: a métissage with an Hispanic cultural phenotype, inscribed in the becoming of the European civilization. A hundred years later, mexicanidad means an achieved racial and cultural métissage between civilizatory antagonisms: the spirit of the ancient, venerable and original Indian civilization and the cultural attributes of the Spanish race. This imagined national(ist) tradition treasures as a guarantee seal of mexicanidad, an Indian cultural phenotype: the Indian hands (spiritual expression) of the Spanish race (LOZOYA, 2010, CONACULTA).

In this latter epical imaginary of the Mexican nation, the viceroyal period (mainly named as colonial period) interferes. It is imagined as a stage in which racial and cultural unification of the motherland is not only not achieved, but the true tradition besieged and submitted to otherness. The Indian spirit is one of resiliency. Thus, Independence (thought as a revenge towards the imperial conquest, instead of a complex civil war among novo hispanos due to the implosion of the Spanish Monarchy) is the fair rebirth of the true nation, and the Mexican Revolution (1910-1920), finally returns true tradition to its legitimate place. The story of the great Mexican defeat will be privileged between the forties and the nineties (and still hardly questioned), by the nationalist historiography of the monopolist party in government: the Partido Revolucionario Institucional (PRI).

The thing is, that there are different historiographical ways of assuming defeats. As Marc Bloch would write in L'étrange défaite, defeat is not definitive if through a collective awareness, the defeated nation assumes its responsibility in the outcome of such historical events. In Mexican contemporary historiography the Pre-Hispanic defeat prevails as an excuse for victimism be it in the epics of nineteenth century's civil wars as reivindications of such a drama, or in any kind of response towards a foreign intrusion in the past two hundred years (from French positivism to global thought). The besieger of any kind of non-true mexicanidad (namely Modernitiy) is mainly imagined as otherness. Collective awareness, then, seems stucked in a silent historical 
irresponsability: the glorious Indian Eden (no questions asked about why is it national) when Mexico was not besieged (no questions asked about the imperial politics of PreHispanic world), was defeated by a modern civilization (let's keep Ricoeur sense of postcolonial revenge in mind!) plunging the nation into an extravagant historical delirium: modernity.

This particular heterogeneous immediate world of associations between mediators such as images, T-shirts, places, narratives, people, politics, ideologies, imaginaries, toure guides, etcetera, that create and expose silently the urban images of victimism, is a practice; a practice of modernity in which from Cuauhtémoc to Frida Kahlo, the images of victimism are very well sold among victims and penitents. Fortunately, for both worlds, María Sabina's T-Shirt are also in sale!

\section{So, briefly...beyond.Mande!}

"Sound is not independent, it does not exist by itself, but has a permanent, constant and unavoidable relationship to silence." (BARENBOIM, 2009: p. 7) The struggle, blend or clash between the imaginaries of mexicanidad and the impact of Rem Koolhaas' gender city, comes out of the silent images of victimism that precedes it. This silence is a modern sound dwelling in the Dark Matter of an urban universe with more than twenty million peaks. Tradition stands to Modernity? Should we keep on looking at the stars?

Gigantic Mexican flag in Mexico City. 2011

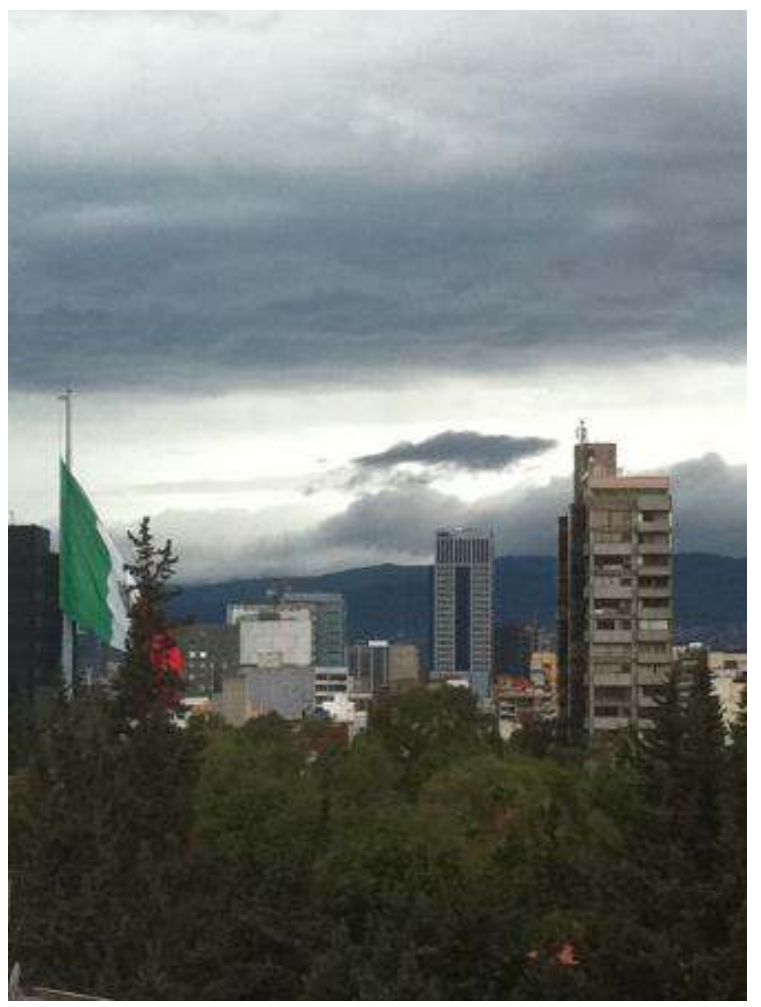

Photo: Johanna Lozoya 


\section{BIBLIOGRAPHY}

ARREDONDO, C. (1998), "La modernidad en la arquitectura de México. El caso de la Ciudad Universitaria", en Modernidad en la arquitectura de México, Edward Burian, Gustavo Gili, México.

BARENBOIM, D. (2009), Music Quickens Time, Verso, London-New York.

BRUCKNER, P. (2008), La tiranía de la penitencia. Ensayo sobre el masoquismo occidental, Ariel, Barcelona.

HOBSBAWM, E. y RANGER, T. (2002), La invención de la tradición, Crítica, Barcelona.

LATOUR, B. (2007), Nunca fuimos modernos. Ensayo de antropología simétrica, Siglo XXI Editores, México.

LOZOYA, J. (2010), Ciudades sitiadas. Cien años a través de una metáfora arquitectónica, Colección Centenarios, № 9, Tusquets, México.

LOZOYA, J. (2010), Las manos indígenas de la raza española. El mestizaje como argumento arquitectónico, CONACULTA, México.

LOZOYA, J. (2005), “La arquitectura como poder y el Estado como imagen: imaginarios modernos arquitectónicos en el totalitarismo mexicano, 1950-1970", en Image et Pouvoir, coord. Jean Claude Seguin y Phillipe Merlot, Université Lumiere, Lyon, pp. 305-317.

LOZOYA, J. (2005), “Imagen e identidad: arquitectura del no lugar, México 1990-2000”, en Revista Iberoamericana, Madrid, Nueva Época, Año V, № 18, junio, pp. 25- 37.

LOZOYA, J. (2011), “Pensamiento sitiado. Imaginarios de la ciudad dependiente latinoamericana”, en Memorias Iberoamérica: la ciudad y el poder, Universidad Nacional de Colombia, Bogotá.

RABOTNIKOF, N. (2005), En busca de un lugar común. El espacio público en la teoría política contemporánea, Instituto Investigaciones Filosóficas - UNAM, México. REID, M. (2009), Forgotten Continent. The Battle for Latin America's Soul, Yale University Press, New Haven and London.

RICOEUR, P. (1965), Universal Civilization and National Cultures, en History and Truth, Evanston, Northwestern University Press.

TOCA, A. (2008), Entrevista en Arquitecturas finiseculares en México, Alejandro Aguilera (ed. y comp), Universidad Iberoamericana, México, pp. 17-21.

VARGAS, R. (1994), “El imperios de la razón”, en La arquitectura mexicana del siglo XX, Fernando González Cortázar, CONACULTA, México.

\section{ABSTRACTS}

Have the cultural, social, economical dynamics of Rem Koolhaas' imaginaries of a generic city triggered a weakening and/or crash of traditional nationalist imaginaries in Mexico City with such a fiction of modernity? Not really, not yet, no need. The following paper deals with the sonorous idea of modernity vs tradition in contemporary urban images(inaries) of mexicanidad. Far from seeing them as an antagonistic association, the author considers that both cultural constructions reveal the practice of a silent historiographical construction: the modern invention of Mexican victimism.

Los imaginarios de la ciudad genérica imaginada por Rem Koolhaas, han detonado el despertar y/ 
o un choque con los imaginarios nacionalistas en la Ciudad de México? No realmente, no aún, no necesariamente. El presente artículo se interesa por la sonora oposición modernidad vs tradición en la imaginarios urbanos contemporáneos de mexicanidad. Lejos de conceptualizarla como una relación de antagonismo, la autora considera que ambas construcciones revelan la práctica de una silenciosa construcción historiográfica: la invención moderna del victimismo mexicano.

L'imaginaire de la ville générique de Rem Koolhaas a-t-il déclenché à Mexico un éveil et/ou un affrontement avec l'imaginaire nationaliste ? Pas vraiment, pas encore, pas nécessairement. Cet article s'intéresse à la sonore opposition entre tradition et modernité dans les imaginaires urbains contemporains de la mexicanité. Loin d'être conceptualisée comme une relation d'antagonisme, l'auteure considère que les deux constructions révèlent la pratique d'une construction silencieuse d'ordre historiographique: l'invention de la victimisation mexicaine moderne.

\section{INDEX}

Keywords: tradition, modernity, mexicanidad, victimism, historiography, imaginaries, silence, Mexico City

\section{AUTHOR}

\section{JOHANNA LOZOYA}

Writer, cultural historian and architect. Coordinación de Investigación en Arquitectura, Urbanismo y Paisaje, Facultad de Arquitectura, UNAM México 